Giorgos Kataliakos

University of Cyprus

\title{
BAD INFLUENCES FROM OUTSIDE: STATE ANTI-COSMOPOLITANISM IN HOBBES' LEVIATHAN
}

homas Hobbes' ideas concerning the right education of the citizen and the subsequent sense of indoctrination caused by the dissemination of foreign political teachings into native English lands, is an issue of great interest that has been largely overlooked in the relative literature. This article is a part of the work in progress which aims to broaden the discussion concerning Hobbes' thoughts about education and the prominent position that this aspect holds in his civil science as a whole.

The main focus of this text is to explore Hobbes' proclaimed concerns about the unrestricted dissemination of political knowledge among misinformed citizens with controversial beliefs and about the possible undesirable consequences of this dissemination. The term "State anti-cosmopolitanism" that I will be employing here proposes a reading of Hobbes that detects elitist and exclusivist (hence anti-cosmopolitan) operations at work in his political theory of pedagogy. It will be shown that Hobbes singles out the instructor and scholar as the paradigmatic cosmopolitan figure of the time. This figure is "provided with the antidote of solid reason" ${ }^{1}$ and by being protected from the risks of indoctrination, he thereby protects the "borders" of learning and staves off the political consequences that Hobbes deems dangerous to the masses. For the purpose of this analysis I mainly concentrate on Leviathan while sporadically drawing insights from Hobbes' mature works that resonate with his educational thought. ${ }^{2}$

1 T. Hobbes, "Leviathan or the Matter Form and Power of a Commonwealth Ecclesiastical and Civil," ed. W. Molesworth, The English Works of Thomas Hobbes of Malmesbury, vol. 3, London, 1997, 314.

2 For the aim of this article I mainly focus on his core political narrative Leviathan while following his supplementary defense of his political doctrine as found in the letter 


\section{Popular ideas and the meaning of foreign sedition}

In his political treatise Hobbes arrives at a list of reasons capable of leading people to seditious behavior against, and disloyalty to, the Sovereign order. ${ }^{3}$ Interestingly, he portrays seven "seditious doctrines" capable of undermining the State, however one is not categorized as such. It is characterized by the author as a "false doctrine." The reason for this alternative category is the wrong reception of the foreign intellectual material that comes from ancient Greeks and Romans. According to Hobbes, such material may cause serious damage to the Hobbesian Sovereign agency. ${ }^{4}$

Hobbes' great concern about the uncontrolled dissemination of foreign political material in native English lands can be traced, on many occasions, throughout the second part of Leviathan, "Of the commonwealth" and in Behemoth. ${ }^{5}$ This concern becomes more comprehensive in chapter 29 of Leviathan where Hobbes identifies the reasons which can lead a commonwealth to its ultimate destruction. ${ }^{6}$ Chapter 29 acquires central significance when we consider Hobbes' basic proposition in Leviathan: that is, a discourse "occasioned by the disorders of the English civil war," a war to which Hobbes was an active witness (1642-49). ${ }^{7}$ Hobbes renders the false doctrine that leads to possible sedition as follows:

... as to rebellion in particular against monarchy, one of the most frequent causes of it is the reading of the books of policy and histories of the ancient Greeks and Romans; from which young men, and all others that are unprovided of the antidote of solid reason, receiving a strong and delightful impression of the great exploits of war achieved by the conductors of their armies, receive withal a pleasing idea of all they have done besides; and imagine their great prosperity not to have proceeded from the emulation of particular men, but from the virtue of their popular form of government . . 8

\footnotetext{
"Six Lessons to the Savilian Professors of the Mathematics," in: The English Works of Thomas Hobbes of Malmesbury, Vol. 7, London, 1997 and also in his "Behemoth: The History of the Causes of the Civil Wars of England," in: The English Works of Thomas Hobbes of Malmesbury, Vol. 6, London, 1997.

3 T. Hobbes, Leviathan, Chapter 29: "Of those things that weaken or tend to the dissolution of the Commonwealth."

${ }^{4}$ Ibidem, 339.

5 Ibidem, 21: 201-03, 29: 314-16, 30: 326-27; Behemoth, 168, 218.

6 T. Hobbes, Leviathan..., Chapter 29, 308.

7 Ibidem, "Review" and "Conclusion."

8 Ibidem, 29: 314-15.
} 
... From the reading, I say, of such books, men have undertaken to kill their kings, because the Greek and Latin writers in their books and discourses of policy make it lawful and laudable for any man so to do, provided before he do it he call him tyrant. For they say not regicide, that is, killing of a king, but tyrannicide, that is, killing of a tyrant, is lawful ...?

These passages indicate Hobbes' fear of non-domesticated historical ideals. Despite the fact that Hobbes himself was greatly indebted to ancient Greek and Roman ideas, he was worried about the possibility that these ideas were to become widely disseminated among the young. Young people's minds, claims Hobbes, were like "white paper," vulnerable to misconceptions, and consequently regarded as an open threat to "monarchy" of which Hobbes was a thorough supporter. Limiting the means by which seditious education might be disseminated in universities and subsequently affect the young would effectively lead to limiting the possibilities of possible discontents and rebellions. ${ }^{10}$

In both passages we notice what Hobbes sees as an obvious misconception related to the reading of Ancient Greeks and Romans by which young people get carried away and deceived: young people are inclined to a reading of Ancient Greeks and Romans that promptly attributes virtues and prosperity to ancient popular forms of government and not to the virtue and charisma of great men in power, as Hobbes would recommend. ${ }^{11}$ This argument thoroughly reflects Hobbes' commitment to monarchy. It also reflects his ambivalent belief that narratives associated with popular forms of government can be interpreted, even by common students, in such a way that presents no political risk. Through the assistance of appropriate educators the "readings" of such narratives can be taught in a manner consistent with monarchical beliefs and ideas. This pedagogical assistance from loyal educators could decrease potential contamination from the narratives among youths and ultimately decrease possibilities of civil disobedience and acts of rebellion. However, it is worth considering what the reasons were that made Hobbes skeptical about the dissemination of Ancient Greek and Roman ideas among the young.

Hobbes attributes the corruptive nature of Ancient Greek and Roman ideas to the way the young receive and treat these ideas, in relation to democracy. Students attending universities at those times were educated to admire the political

\footnotetext{
9 Ibidem, 315.

10 T. Hobbes, "Six Lessons to the Savilian Professors of the Mathematics"..., 335.

11 Leviathan, 29: 315, 21: 201.
} 
writings of Aristotle and Cicero, both of whom were figures of great respect and influence for any thinker delving into philosophy and politics, much like Hobbes was. Both Aristotle and Cicero had much to say about politics, policies, and good government. However, both lived under popular states and expressed democratic ideas which were opposed to "monarchy." For Hobbes, the dissemination of these types of discourse added tension to the already crucial period of civil war in England. ${ }^{12}$ Given the context, Hobbes preferred and proposed a distance from those foreign ideas that he considered infectious and dangerous.

As Geraint Parry points out, Hobbes did not quite accuse ordinary people of merely misreading narratives from classical scripture. ${ }^{13}$ Those he blamed for the "misinterpretation" of the classics were none other than the universities and the people of high intellectual esteem who were charged with the duty of educating the young according to the will of the sovereign. It is the "preparation of that mediating role" ${ }^{14}$ assigned to the universities for accommodating the flow of knowledge for the sake of peace and stability that seemed deeply vulnerable and needed considerable changes. In his answer to "the Savilian Professors of the Mathematics" Hobbes defended the idea that his doctrine in Leviathan should be interpreted by "wiser men" in such a way that could "fit better for public teaching." ${ }^{15}$ His exaggerated belief that he could press reforms to happen by recommending "true doctrine" also involved the idea that his doctrine could actually cure the controversial reading of foreign political doctrines and the uncontrollable publishing of politically dangerous texts.

Another argument indicative of Hobbes' overarching skepticism toward Ancient Greek and Roman writings relates to the writer's own venture in life and to his duties as a secretary to the chancellor and as "keeper of secrets." Following Kinch Hoekstra's influential exploration on Hobbes' early correspondence, we find evidence that discreet behavior and secrecy were some of the core characteristics that marked the author's intellectual career. ${ }^{16}$ In a letter received by Hobbes in December 1622 from a friend of his called Robert Mason there seems to be a mutual agreement on the idea that some affairs of the state are expect-

\footnotetext{
12 G. Parry, "The Sovereign as Educator: Thomas Hobbes's National Curriculum," Paedagogica Historica, 34:3 (1998): 711-730.

13 T. Hobbes, Leviathan..., 712.

14 Ibidem, 712.

15 T. Hobbes, "Six Lessons to the Savilian Professors of the Mathematics"..., 335.

${ }^{16}$ K. Hoekstra, "The End of Philosophy (The Case of Hobbes)," Proceedings of the Aristotelian Society, Vol. 106 (2006): 25-62.
} 
ed to remain "closely and secretly managed $\&$ not so much as whispered of." 17 Mason gives voice to Hobbes' thoughts concerning the communication of state affairs to common citizens and the assumption that some affairs should not be revealed into the public sphere. ${ }^{18}$ This view chimes with arcana imperii, namely, "the mysteries of the State," and sums up Hobbes' valorization of the strict confidentiality in matters of urgent political concern. Arcana imperii, a phrase of various, rich connotations is part of the epic proverb in Latin that Mason dedicates to Hobbes: "I do not object to the existence of state secrets; One must understand the danger." ${ }^{19}$ This mysterious and confidential version of Hobbes, helps us shed a different light on Hobbes, the political theorist and educator. Hobbes' concern to control the foreign political material which is taught and disseminated among the nation can be seen differently if we turn to possible characteristics and virtues that Hobbes attached to "men of great honour" and educators who differ from those who teach fallaciously popular ideas coming from other nations and times. Textual support of this connection may be found at the very end of the first tract quoted earlier where Hobbes deplores the great error imprinted in common people's minds who do not apprehend rightly and truly the means by which the Ancients earned their prosperity. ${ }^{20}$ Common people tend to believe, as Hobbes points out, that prosperity in those western countries did not emanate "from the emulation of particular men's glorious winnings at the battlefields of war and politics, as they ought to be taught, but instead "from the virtue of their popular form of government." ${ }^{21}$ Hobbes' praise of "particulars" and talented persons proves his deep commitment to monarchy and attests to his strategic readings of history that serve precise ends and purposes.

Some lines later in the passage, Hobbes says that he could never imagine a wider threat to monarchy than the circulation and reading of books that propagate populist beliefs. ${ }^{22}$ Further on, Hobbes refers to the class of "discreet masters" as those capable of removing "the venom" of popular ideas from ancient doctrines or narratives and make the course of teaching more aligned with the

17 The Correspondence of Thomas Hobbes, ed. N. Malcom, Oxford University Press, 1994, Letter 1 December 1622.

18 T. Hobbes, Leviathan..., 41.

19 The proverb is written in Latin as: "Arcana imperii nihil moror periculum intelligere," Correspondence, 4.

20 T. Hobbes, Leviathan..., 315.

21 Ibidem, 315.

22 Ibidem, 315. 
will of the sovereign. ${ }^{23}$ Though Hobbes does not give details about the "discreet master" or about how the master would purify the doctrines, we may conclude that, for Hobbes, discretion implies secrecy and strict confidentiality in matters of political urgency.

In order for the sovereign to ensure correct teaching his strong reliance on scientific reason should be considered as one of his most developed skills. State disorders would never seize to exist until sovereigns reach the point of themselves becoming philosophers that delve in people's minds and souls. ${ }^{24}$ This process, as I argue in the next section, presupposes the deployment of a new political language that, if used appropriately and consistently, may achieve what Hobbes believes to be a steady system of social relations that may guarantee the endurance of a "steady commonwealth."

\section{Elitist education and the need for a new political vocabulary}

Hobbes' theory of education aspires to rely on politically weighted definitions that underpin opinions "truly" valid and thus aligned to the pronouncements of the Sovereign. ${ }^{25}$ Commentators such as J. D. Marshall, G. Perry and M. Bejan have highlighted the major significance given to "the right definitions of things" and to the pivotal role played by language in the deployment of Hobbes' civil science. ${ }^{26}$ This is a very important feature of Hobbesian sovereignty; it is the one that actually cements the indisputable relationship between protection and obedience that is so widely discussed throughout Leviathan.

But first let us examine Hobbes' thoughts concerning language. In the introductory chapters of Leviathan, Hobbes devotes considerable attention to the correct arrangement and use of "language": ${ }^{27}$ for example, the language used

${ }^{23}$ Ibidem.

${ }^{24}$ T. Hobbes, Leviathan..., introduction: x-xi; see also chapter: 31, 357.

25 Ibidem, 164.

${ }^{26}$ J. D. Marshall, "Education and Obligation in the Commonwealth," Journal of Philosophy of Education, Vol. 14, No. 2 (1980): 201-02. G. Parry, "The Sovereign as Educator: Thomas Hobbes's National Curriculum," 1998, 713-715. T. M. Bejan, “Teaching the Leviathan: Thomas Hobbes on Education," Oxford Review of Education, 2010, 36:5, 607-626, 614-615.

27 T. Hobbes, Leviathan..., Chapter 4, 5. 
when practicing public speech must be thoroughly aligned with certain provisional criteria and scientific convictions that are predetermined by the Sovereign's language protocol. Acting otherwise, Hobbes says, will find the speaker "entangled in words, as a bird in lime twigs, the more he struggles the more belimed." 28

For Hobbes, the course of thought and demonstration of knowledge follows the principles of mathematics, especially those of addition and subtraction. Following Hobbes, adding together "two words" makes an "affirmation," "two affirmations" make a "syllogism," "many syllogisms" make a "demonstration" and "from the sum (we) subtract one proposition to find the other." ${ }^{29}$ True science in this sense is the awareness that any action or many actions conjoined together lead to definite decisions and unaltered consequences. At the same time, where these aforementioned principles are deployed there is also permission to treat "reason" and, similarly, political understanding and judgment accordingly. ${ }^{30}$

For Hobbes, true perceptions are validly registered in people's minds only when different parties agree to authorize some arbitrators or a trusted judge to take on the task of "the supreme lexicographer." 31 Thus, sovereignty, for Hobbes, emerges due to the people's urgent need to find common ground in language and to build upon common premises regarding the "State," "individual rights," "welfare," "protection," "obedience," and "duties." When no agreement is met, then people become vulnerable to vague terminology. ${ }^{32}$

Nevertheless, the invention of scientific language along with its reception and application continue to create difficulties for Hobbes even when people are civilized under the aegis of the sovereign. Civilized people are still vulnerable to errors because educators are ambivalent about committing to the words of the native Sovereign. The reason why educators (and common people) are unsure is because they are interacting with scholars like Aristotle and Cicero whose "words" were predicated to serve completely different and controversial political purposes from the ones "truly" undertaken by the sovereign. One of the principal duties that people have to perform while living under Hobbes' sover-

28 Ibidem, Chapter 4, 25.

${ }^{29}$ K. Hoekstra, "The End of Philosophy (The Case of Hobbes)," 16, 30.

30 T. Hobbes, Leviathan..., 30.

31 The term is used by Geraint Parry in "The Sovereign as Educator" (713) with special reference to Sheldon Wolin, Politics and Vision: Continuity and Innovation in Western Political Thought (London: Allen and Unwin, 1961).

32 Ibidem, 713. 
eign is "not to be in love with any form of government they see in their neighbor nations, more than with their own." 33 Avoiding imitation of foreign affairs matches Hobbes' plea to abandon the whole course of reading foreign doctrines that demonstrate a lexicon that is entirely irrelevant to that suggested by the "sovereign."

\section{State anti-cosmopolitanism}

By opening up the issue of "bad imprinting" in Hobbes theory, in other words, the influence of foreign (and consequently dangerous) doctrines, we are led to the issue of cosmopolitan openness to encounters with otherness and of how the influential other comes up in Hobbesian thought; hence the relevance of the term "State anti-cosmopolitanism" that I will sketch here. First let us ask: who is susceptible to contamination from bad imprinting according to Hobbes? Is it the educator or is it the student and future citizen?

The answer seems evident (namely, the student) but becomes more ambiguous if we realize that Hobbes portrays both agents as vulnerable to vice due to the infectious effect that the dissemination of seditious doctrine has in society and the obvious incapacity of the State to maintain control. Both the educator and the student are inextricably affected by seditious doctrines because they both lack commitment to the sovereign's doctrine. Hobbes invites the educators to stay put and defend their positions by seeking re-education on the principles of the true civil doctrine.

Hobbes says in Behemoth that universities which, as we understand, hold the seats of elite education "are the fountains of civil and moral doctrine, from whence the preachers and the gentry, drawing such water as they find, use to sprinkle the same (both from the pulpit and in their conversation) upon the people." ${ }^{4}$ The objective of true politics as taught in the universities, says Hobbes, should be chiefly directed by the ultimate educator in principle who is none other than the sovereign himself. Thoroughly equipped with the means of an innovative "science of speech" and "right reason" he should perform his duties of teaching true politics first to his chosen

\footnotetext{
${ }^{33}$ K. Hoekstra, "The End of Philosophy (The Case of Hobbes)," 326.

${ }^{34}$ T. Hobbes, Behemoth..., 236.
} 
personnel consisting of public ministers "authorized to teach or enable others to teach," ${ }^{35}$ preachers, and gentlemen of the best sort "that imbibe good principles in their youth at the universities." 36

Actual educators follow next in Hobbes' hierarchy, where they form a sort of "critical mass." Their duty should be to follow the words of the sovereign letter by letter and number by number; their teachings should be carefully monitored by public ministers who would have complete and inalienable authority over them. At the bottom of the hierarchy stands the learner whose bizarre naiveté, declared misunderstanding and natural capacity to desire novelty leaves him unprotected from the risks of indoctrination and contamination. It is easy for the learner to get carried away but also capable for him/her to remain loyal, if the course of learning is safely regulated and abides to the scriptures of the sovereign.

The term "State anti-cosmopolitanism," which I wish to use here, has affinities with what Leo Strauss calls "the movement away from the study of past (present) States to the free construction of the future state." 37 "State anti-cosmopolitanism" refers to the urgent need undertaken by the Hobbesian sovereign to conceptualize a theory of the State based solely upon his own appeal to reason and thus independent from bad influences which stem from foreign political doctrines. The employment of a new political language against the "foreign others" who question the supreme authority of the State could provide new analytical instruments for explaining domestic politics and regulating foreign influence at the time of Hobbes' writing. Educators, under the guidance of public ministers, would be instructed to perform "duty" and secure political stability through education, where common citizenry would remain untouched by foreign doctrines and thus protected from foreign indoctrination.

By using education and language under the auspices of Hobbes' Leviathan, the nation forms not only a defense against the "foreign other," but also an ideal strategy, as led by the Sovereign, to resolve internal conflict and restore the nation's lost dignity in the international sphere.

35 T. Hobbes, Leviathan..., 228.

36 T. Hobbes, Leviathan..., 228. See also in Behemoth, 237.

37 L. Strauss, The Political Philosophy of Hobbes: Its Basis and Its Genesis, The University of Chicago Press, 1936, 129. 